\title{
Effect of Dietary Modified-Banana-Tuber Meal Substituting Dietary Corn on Growth Performance, Carcass Trait and Dietary-Nutrients Digestibility of Coloured-Feather Hybrid Duck
}

\author{
Sjofjan O, Adli DN, Natsir MH, Nuningtyas YF, Wardani TS, Sholichatunnisa I, Ulpah SN, Firmansyah O \\ Department of Feed and Animal Nutrition, Faculty of Animal Science, Universitas of Brawijaya, Jl. Veteran, Malang, East Java 65145 - \\ Indonesia \\ E-mail: osofjan@yahoo.com
}

(received 30-01-2021; revised 18-03-2021; accepted 06-04-2021)

\begin{abstract}
ABSTRAK
Sjofjan O, Adli DN, Natsir MH, Nuningtyas YF, Wardani TS, Sholichatunnisa I, Ulpah SN, Firmansyah O. 2021. Pengaruh pakan tepung bonggol-pisang-modifikasi (TBP-M) sebagai bahan pengganti jagung pada kinerja pertumbuhan, karakter karkas dan daya cerna pakan itik hibrida (Peking $x$ Khaki Campbell). JITV 26(1): 39-48. DOI: http://dx.doi.org/10/14334/jitv.v26i1.2686.

Penelitian bertujuan untuk mengetahui pengaruh penggunaan tepung bonggol pisang modifikasi (TBP-M), hasil perlakuan tepung bongkol pisang dengan enzim selulase, dan di stabilkan nilai nutrisinya menggunakan tepung daging-tulang, DLmethionin, dan lisyne terhadap nilai nutrisi, performans produksi, kualitas karkas dan kecernaan pakan itik hibrida (Peking $\mathrm{x}$ Khaki Campbell). Materi dalam penelitian ini 196 itik pedaging hibrida dengan rataan bobot hidup $(421.31 \pm 0.183 \mathrm{~g})$. Metode penelitian yang digunakan adalah Rancangan Acak Lengkap dengan 5 perlakuan dan 4 ulangan. Pakan percobaan terdiri dari kontrol (tanpa substitusi TBP-M), TBP-M25 (Pakan basal + TBP-M 25\% substitusi jagung), TBP-M50 (Pakan basal + TBP-M 50\% substitusi jagung), TBP-M75 (Pakan basal + TBP-M 75\% substitusi jagung), TBP-M100 ( Pakan basal + TBP-M 100\% substitusi jagung). Data hasil penelitian dianalisis secara statistik dengan analisis keragaman (Anova, analysis of variance). Dilanjutkan dengan uji Duncan's Multiple Range Test untuk mengetahui perbedaan rataan antar perlakuan dengan menggunakan perangkat lunak SAS. Hasil penelitian menunjukkan bahwa substitusi jagung dengan TBP-M berpengaruh nyata $(\mathrm{P}<0,05)$ terhadap kecernaan bahan kering dan protein kasar pakan. Disimpulkan bahwa TBP-M dapat diberikan sebagai pengganti jagung tanpa menimbulkan efek negatif pada itik hibrida.
\end{abstract}

Kata Kunci: Karkas, Kecernaan gizi pakan, Itik hibrida, Bongkol pisang modifikasi

\section{ABSTRACT}

Sjofjan O, Adli DN, Natsir MH, Nuningtyas YF, Wardani TS, Sholichatunnisa I, Ulpah SN, Firmansyah O. 2021. Effect of dietary modified-banana-tuber meal (M-BTM) substituting corn on growth performance, carcass traits and dietary-nutrients digestibility of coloured-feather hybrid duck (Pekin x Khaki Cambell). JITV 26(1): 39-48. DOI: http://dx.doi.org/10/14334/jitv.v26i1.2686.

In this experiment, we investigate the effect of modified banana tuber meal (M-BTM) to substitute dietary maize in growingfinisher colored-feathered hybrid duck. One hundred and ninety six hybrid ducks (Pekin x Khaki Campbell) with $421.31 \pm$ $0.183 \mathrm{~g}$ body weight (BW) were allotted to 5 dietary treatments with 9 ducks (unsexed) per pen and 4 replications per treatment. These dietary treatments were: NC (negative control; maize-soyabean-meal based diet), BTM25 (25\% maize was replaced by MBTM-), BTM50 (50\% maize was replaced by M-BTM), BTM75 (75\% maize was replaced by M-BTM), and BTM100 (100\% maize was replaced by M-BTM). The experimental design applied using completely randomize design (CRD). Data of this experiment were statistically analysed by one-way-analysis-of-variance of SAS University version 4.0 red hat (64-bit) University Online Edition. Result demonstrated that M-BTM improved significantly $(\mathrm{p}<0.05)$ digestibility of dry matter and crude protein. It is concluded that M-BTM enhanced apparently growth performaces and digestibility parameters of colored-feathered hybrid duck (Pekin x Khaki Campbell).

Key Words: Carcass, Digestibility of energy, Hybrid ducks, Modified banana tuber meal

\section{INTRODUCTION}

Demand for poultry products have raised every year, according to Sjofjan et al. (2021) the poultry protein needed raised year to year. Poultry, especially broiler contribute more than $50 \%$ protein requirement in
Indonesia. One of secondary meat protein source can be fulfilled from waterfowl (Sjofjan et al. 2021). One of the popular waterfowl as meat in Indonesia were Hybrid duck. Hybrid ducks are the offspring of a crossing between a male Peking duck and female Khaki Champbell duck. Peking ducks have rapid weight gain, 
while Khaki Champbell ducks have a high body weight and high egg production compared to other local ducks (Sjofjan et al. 2021). Duck has a considerable high feed consumption compared to chicken; therefore feed has to be considered seriously. At least $65-75 \%$ of total productivity in poultry industry is allocated for feed (Ali et al. 2014).

The Indonesian government imposed regulation Permendag/10/2020 to anticipate the COVID-19, the Indonesian government has undertaking strict quarantine measures on the importation of live animal species and imported feed material originating from China or transiting into Indonesian territory (Badan Pusat Statistik 2020; Sjofjan et al. 2021). Thus, regulation causes reducing supply of raw material for poultry feed such as maize (Sjofjan \& Adli 2021). Fourthly quarter (Q4) data from Badan Pusat Statistik (2020) reported that Indonesia imported maize at the amount of 911.194 tonnes/year or equally to a total rate of US\$ 233.47 million. The maize is a main feed ingredient for poultry industries in Indonesia. Later, the industrial of feed mill, institution, academic, researcher, and farmers in Indonesia took an alternative to solve this problem by using potential local material in area scopes. The used of tuber meal in poultry diet are in partial replacement of maize. This was expected since the cost of tuber meals is much lower than that of maize (Beckford \& Bartlett 2015; Achilonu et al. 2018).

One potential feed to replace maize were banana tuber meal since this root meal had similar energy content and low protein but high in crude fiber. The Indonesia has potential agro-industrial waste from banana plant. According to Hapsari et al. (2017), Indonesia is homeland of banana both wild species and cultivars. Moreover, banana is most famous fruit plant through worldwide. Being part of primary data of origin and biodiversity of banana, Indonesia has played a crucial role in supporting availablity of banana (Hapsari et al. 2017). Banana plant had tuber or rhizome, which is a basal part of banana stem. Rhizome grew after reproductive organ were formed as modification of the peduncle, white in color, with smooth surface. Rhizome consists of epidermis, periphery zone and center zone (Sumardi \& Wulandari 2010; Libatique 2020).

There is a negative effect of utilizing banana tuber which causes gizzard erosion, low palatability, and low nutrient content. Thus, tuber meal needs to be modified in accordance to overcome the weakness. To improve its nutrient content, the modification utilize $\beta$-cellulose enzyme. The tuber contents 50\% undigestible nonstarch polysaccharide (NSP) component for poultry. The local resources as an alternative feed ingredient for poultry was reported to stimulate the releasing of volatile fatty acid in the caecum of ducks and reduced crude fiber in the gut of waterfowl (Sharmila et al.
2014). However, its use in conventional feed is limited by some factors and need to be well managed before using it as commercial livestock feed (Dei et al. 2011).

Accordingly, this study was carried out to investigate the effect modified banana tuber meal to promote replacement of maize in growing-finisher rations of colored-feathered hybrid. Then, choosing the most suitable level of treatment applicable in duck farm is considered to be a novelty of the result of the experiment.

\section{MATERIALS AND METHODS}

\section{Ducks rearing condition}

One hundred and ninety six colored-feathered hybrid ducks (Pekin x Khaki Campbell) with average $421.31 \pm 0.183 \mathrm{~g}$ of body weight were allotted to 5 dietary treatments with 9 ducks (unsexed) per pen and 4 replications each treatment. Furthermore, the second experiment for digestibility, 20 hybrid ducks (Pekin $\mathrm{x}$ Khaki Campbell) aged 64 days (unsexed) were used. The total 20 metabolic cages were used. One cage for one duck. The experiment was conducted at conventionally-farm-controlled environmental, at Batu, East Java, Indonesia (latitude $7^{\circ} 55^{\prime} 06^{\prime \prime} \mathrm{S}$, longitude $112^{\circ} 34^{\prime} 35^{\prime \prime} \mathrm{E}$, elevation $813 \mathrm{~m}$ ). The climate is tropical wet season and average rainfall around $3230 \mathrm{~mm}$. The average room temperature and humidity were $26^{\circ} \mathrm{C}$ and $71 \%$, respectively. Rice hull was used as litter floor pens. The lighting program was set at 16 hours light. Ducks were reared under supervision of a veterinarian and was approved by the University of Brawijaya Animal Ethics Committee. The hybrid duck were taken from commercial farmer from Blitar Regency, East Java, Indonesia.

\section{Feeding treatment programmed}

The ducks were given free access (ad libitum) to fresh water and feed throughout the study period twice a day at 07; $30 \mathrm{AM}$ and 15; 30 PM. Experimental diets were formulated according to growing phase of day 24 to day 38 for first phase, day 39 to day 52 for second phase and day 53 to day 64 for finisher phase. The Composition of Feed in the experiment is presented in Table 2, 3 and 4, respectively for first, second and finisher phases.

\section{Preparation of modified banana tuber meal}

The banana tuber meal (BTM) were taken from local merchant at the wet-local-market, in Trenggalek city, East Java, Indonesia. The tuber meal was sifted to 
Table 1. Nutrient composition of diet ingredient (g/kg, as-fed basis)

\begin{tabular}{lccc}
\hline \hline Item & Maize & Soybean meal & Banana tuber meal \\
\hline Dry Matter, $(\mathrm{g} / \mathrm{kg})$ & 91.4 & 91.3 & 86.3 \\
Crude protein, $(\mathrm{g} / \mathrm{kg})$ & 8.3 & 41.5 & 36.1 \\
Fat, $(\mathrm{g} / \mathrm{kg})$ & 40 & 16 & 45 \\
Crude fibre, $(\mathrm{g} / \mathrm{kg})$ & 17 & 34 & 16.7 \\
Ash, $(\mathrm{g} / \mathrm{kg})$ & 25 & 58 & 6.7 \\
Nitrogen free extract, $(\mathrm{g} / \mathrm{kg})$ & 554 & 300 & 435 \\
\hline
\end{tabular}

separate the meal from the remaining stem-foliage, then placed on the floor that had been covered with trash bags and plastic. Suspensions of $\beta$-Cellulose are homogenized in a blender with $0.5 \%$ of meat-bone-meal then added at $0.010 \%$ per $1 \mathrm{~kg}$ of BTM. The treated BTM was the named as modified TBM (M-TBM). The last step was formulation with DL-Meth and Lysine on total feed formulation that are presented in Tables 2,3, and 4. The dietary treatments were: NC (negative control; maize-soya bean-rice bean-meal based diet), M-BTM25 (25\% of maize was replaced with M-BTM), M-BTM50 (50\% of maize was replaced with M-BTM), M-BTM75 (75\% of maize was replaced with M-BTM), M-BTM100 (100\% of maize was replaced with MBTM). Diets were formulated to contain $2900 \mathrm{kcal}$ metabolizable energy (ME) $/ \mathrm{kg}, 18 \%$ crude protein, $0.75 \%$ total methionine and $0.28 \%$ total lysine. The other nutrients were formulated to meet or slightly exceed the nutrient requirement as suggested by Badan Standardisasi Nasional (2018). Experimental diets were formulated using Universitas Brawijaya (UB) Feed Formulation Software for Poultry following Badan Standardisasi Nasional (2018) requirement.

\section{Data collection and sampling procedures}

Daily feed consumption was recorded by measuring daily weight difference between feed offered and feed left. The weekly live weight of the duck was measured weekly at 06:00 AM. The feed efficiency was then calculated by dividing the total feed consumption by the live weight gain of the ducks during experiment (Abel et al. 2015). Duck mortality was recorded per flock from the beginning until the end of the experiment (Sjofjan et al. 2021). Twenty-four ducks from each pen which had weight to the nearest final live weight gain were taken to be sacrificed for carcass analyses.

\section{Digestibility's analyses}

The digestibility method was carried out by sampling the homogenized feces collected and stored in plastic trays. Then, immediately placed mixture of liquid of $\mathrm{NA}_{2} \mathrm{PO}_{4} \quad 2 \% ; \quad \mathrm{NA}_{2} \mathrm{H}_{2} \mathrm{PO}_{4} \quad 2 \%, \quad 24 \%$ formaldehyde; and $900 \mathrm{ml}$ reverse osmosis water for digestibility's analysis following Sjofjan et al. (2021). Data were used to calculate digestibility parameters according to the following formulae:

\section{AME=IE-FE \\ $\mathrm{TME}=\mathrm{AME}+\mathrm{FEL}$}

Where IE=ingested energy; FE=fecal energy voided by the fed birds; while FEL=fasting energy loss by the unfed birds, apparent metabolizable energy (AME), nitrogen-corrected apparent metabolizable energy (AMEn), total metabolizable energy (TME), nitrogencorrected total metabolizable energy (TME). The values corrected to zero $\mathrm{N}$ balance, AMEn and TMEn, were calculated as follows:

\section{AMEn=AME $-(8.22 \times$ ANR/FI $)$ \\ TMEn=TME $-(8.22 \times F N L / F I)-(8.22 \times A N R / F I)$}

Where ANR=apparent $\mathrm{N}$ retention; FI=feed intake; and FNL=fasting $\mathrm{N}$ loss by the unfed bird; the factor $8.22 \mathrm{kcal} / \mathrm{g}$ for $\mathrm{N}$ retained in the body has been used according to Mustafa et al. (2004) and Sjofjan et al. (2021). Continually, the analyses of proximate of the feed sample was carried out to determine dry matter, ash, crude fibre, fat, and crude protein contents (Sjofjan et al. 2021). Crude protein was determined using Kjeltech analyses of Foss Detector, Switzerland and gross energy was determined using Parr Oxygen Bomb 1108; USA (Sjofjan et al. 2021).

\section{Data analyses}

The experimental design applied was completely randomize design (CRD). Data of experiment were statistically analysed by the one-way-analysis-ofvariance of SAS University version 4.0 red hat (64-bit) University Online Edition (Sjofjan \& Adli 2021). The differences among treatment means were determined at level of $\mathrm{p}<0.05$, using Duncan's multiple range test (Steel \& Torrie 1990). 
Table 2. Composition of dietary treatments (as fed basis) fed to second growing phase of colored-feathered hybrid ducks (Pekin x Khaki Campbell)

\begin{tabular}{|c|c|c|c|c|c|}
\hline \multirow[t]{2}{*}{ Ingredients } & \multicolumn{5}{|c|}{ Treatments } \\
\hline & $\mathrm{NC}$ & M-BTM 25 & M-BTM50 & M-BTM75 & M-BTM100 \\
\hline Maize , (g/kg) & 540 & 500 & 490 & 465 & 440 \\
\hline Rice bran, (g/kg) & 150 & 150 & 150 & 150 & 150 \\
\hline Soybean meal, (g/kg) & 120 & 120 & 120 & 120 & 120 \\
\hline Meat bone meal 50, $(\mathrm{g} / \mathrm{kg})$ & 50 & 50 & 50 & 50 & 50 \\
\hline Fish Meal. 60, (g/kg) & 50 & 50 & 50 & 50 & 50 \\
\hline M-BTM, (g/kg) & - & 25 & 50 & 75 & 100 \\
\hline Limestone Powder, (g/kg) & 30 & 30 & 30 & 30 & 30 \\
\hline Grit, (g/kg) & 41 & 41 & 41 & 41 & 41 \\
\hline DL-Methionine, $(\mathrm{g} / \mathrm{kg})$ & 1 & 1 & 1 & 1 & 1 \\
\hline Palm oil, (g/kg) & 10 & 10 & 10 & 10 & 10 \\
\hline$\beta$-cellulase, $(\mathrm{g} / \mathrm{kg})$ & - & 1 & 1 & 1 & 1 \\
\hline L-lysine , (g/kg) & 5 & 5 & 5 & 5 & 5 \\
\hline \multicolumn{6}{|l|}{ Analyzed nutrients composition } \\
\hline Dry matter, $(\%)$ & 87.05 & 87.25 & 87.30 & 87.43 & 87.55 \\
\hline Crude protein, $(\%)$ & 18.01 & 18.11 & 18.19 & 17.38 & 17.56 \\
\hline Fat, $(\%)$ & 6.41 & 6.53 & 6.36 & 6.23 & 6.17 \\
\hline Crude Fiber, (\%) & 3.63 & 3.78 & 3.60 & 4.60 & 4.93 \\
\hline Ash, $(\%)$ & 6.10 & 6.25 & 6.13 & 6.39 & 6.45 \\
\hline Nitrogen Free extract, $(\%)$ & 48.33 & 46.66 & 45.88 & 47.05 & 46.63 \\
\hline Metabolizable energy, (Kcal/kg) & 2,912 & 2,917 & 2,905 & 2,941 & 3,412 \\
\hline Lysine, $(\%)$ & 1.07 & 1.10 & 1.11 & 0.93 & 1.15 \\
\hline Methionine, $(\%)$ & 0.41 & 0.45 & 0.48 & 0.53 & 0.55 \\
\hline Met. + Cystine, $(\%))$ & 0.68 & 0.67 & 0.66 & 0.65 & 0.56 \\
\hline Calcium, (\%) & 3.71 & 3.71 & 3.71 & 3.71 & 3.71 \\
\hline Total Phosphorus, (\%) & 0.85 & 0.87 & 0.85 & 0.86 & 0.88 \\
\hline Available Phosphorus, (\%) & 0.39 & 0.39 & 0.39 & 0.34 & 0.44 \\
\hline Bulk density, (g / L) & 383 & 381 & 381 & 345 & 356 \\
\hline
\end{tabular}


Table 3. Composition of dietary treatments (as fed basis) fed to finisher phase of colored-feathered hybrid ducks (Pekin x Khaki Campbell)

\begin{tabular}{|c|c|c|c|c|c|}
\hline \multirow[t]{2}{*}{ Ingredients } & \multicolumn{5}{|c|}{ Treatments } \\
\hline & $\mathrm{NC}$ & M-ВТМ 25 & M-BTM50 & M-BTM75 & M-BTM100 \\
\hline Maize, $(\mathrm{g} / \mathrm{kg})$ & 550 & 515 & 500 & 475 & 450 \\
\hline Rice bran, (g/kg) & 170 & 170 & 170 & 170 & 170 \\
\hline Soybean meal, $(\mathrm{g} / \mathrm{kg})$ & 90 & 90 & 90 & 90 & 90 \\
\hline Meat bone meal 50, $(\mathrm{g} / \mathrm{kg})$ & 50 & 50 & 50 & 50 & 50 \\
\hline Fish Meal. 60, (g/kg) & 50 & 50 & 50 & 50 & 50 \\
\hline M-BTM, (g/kg) & - & 25 & 50 & 75 & 100 \\
\hline Limestone Powder, (g/kg) & 30 & 30 & 30 & 30 & 30 \\
\hline Grit, $(g / k g)$ & 41 & 41 & 41 & 41 & 41 \\
\hline DL-Methionine, (g/kg) & 1 & 1 & 1 & 1 & 1 \\
\hline Palm oil, (g/kg) & 10 & 10 & 10 & 10 & 10 \\
\hline$\beta$-cellulose, $(\mathrm{g} / \mathrm{kg})$ & - & 1 & 1 & 1 & 1 \\
\hline L-lysine, (g/kg) & 5 & 5 & 5 & 5 & 5 \\
\hline \multicolumn{6}{|l|}{ Analyzed nutrients composition } \\
\hline Dry matter, $(\%)$ & 86.96 & 87.09 & 87.21 & 87.34 & 87.46 \\
\hline Crude protein, $(\%)$ & 15.81 & 15.99 & 16.17 & 16.35 & 16.54 \\
\hline Fat, $(\%)$ & 6.66 & 6.60 & 6.54 & 6.47 & 6.41 \\
\hline Crude Fiber, $(\%)$ & 3.76 & 4.08 & 4.41 & 4.73 & 5.06 \\
\hline Ash, $(\%)$ & 6.15 & 6.21 & 6.28 & 6.34 & 6.40 \\
\hline Nitrogen Free extract, $(\%)$ & 48.91 & 48.48 & 48.06 & 47.63 & 47.21 \\
\hline Metabolizable energy, (Kcal/kg) & 2696 & 2648 & 2600 & 2552 & 2510 \\
\hline Lysine, $(\%)$ & 0.84 & 0.85 & 0.85 & 0.86 & 0.86 \\
\hline Methionine, $(\%)$ & 0.50 & 0.50 & 0.51 & 0.51 & 0.52 \\
\hline Methionine + Cystine, $(\%)$ & 0.75 & 0.76 & 0.76 & 0.77 & 0.78 \\
\hline Calcium, $(\%)$ & 3.71 & 3.71 & 3.71 & 3.72 & 3.72 \\
\hline Total Phosphorus, (\%) & 0.86 & 0.87 & 0.88 & 0.89 & 0.89 \\
\hline Available Phosphorus, (\%) & 0.39 & 0.40 & 0.41 & 0.42 & 0.44 \\
\hline Bulk density, (g/L) & 585 & 584 & 580 & 569 & 565 \\
\hline
\end{tabular}

$\mathrm{NC}=$ negative control; maize-soyabean-meal based diet; M-MBTM25 $=25 \%$ of Modified Banana Tuber Meal replaced maize; M-MBTM50 $=$ $50 \%$ of Modified Banana Tuber Meal replaced maize; M-MBTM75 = 75\% of Modified Banana Tuber Meal replaced maize; M-MBTM100 = $100 \%$ of Modified Banana Tuber Meal replaced maize

\section{RESULTS AND DISCUSSIONS}

\section{Performance of hybrid-duck}

Experimental results are presented in Table 4 and Table 5, it shows that there were no significant difference $(p>0.05)$ on parameters observed. Initially, there were curve linear decrease in the growing phase 1 ,
2, and finisher phase in feed intake as the level of modified banana tuber meal increased in formulated diet (Figure 1). This was incontrast from the finding of Atapattu \& Senevirathne (2013) who reported that the feed intake or feed conversion ratio was not affected by the type of the banana meal. In addition from Sugiharto et al. (2020) using banana peel meal up to $15 \%$ had no deleterious effect on the feed intake of the poultry. 
The result of daily weight gain are presented on the Table 4 , at the beginning phase were $39.1 ; 38.3 ; 37.4$; 35.9 vs. $34.5 \mathrm{~g} / \mathrm{bird}$ (control). The result continued at the second growing phase Table 4 were 59.2; 58.7; $57.8 ; 58.9$ vs. $56.5 \mathrm{~g} / \mathrm{bird}$ (control). For the last, at the finisher phase (Table 4) were 59.3; 58.6; 58.3; 56.1 vs. $54.3 \mathrm{~g} /$ bird (control).

The trends continued positive on the body weight increase, even though the data were not significant difference ( $p>0.05)$. Table 4 showed the body weight at the beginning phase were $714 ; 736 ; 723 ; 747$ vs. 733 (control), then followed on the growing phase 978; 976; 985; 987 vs. 988 (control), at the end phase showed that $1570 ; 1674 ; 1562 ; 1542$ vs. 1558 (control).

The number of mortalities also decreased in accordance with increase in the day of rearing. The increased of daily gain may be in correlation with the modified banana tuber meal, the $\beta$-cellulose enzyme successfully reduced crude fiber and bind some nonstarch polysaccharides (NSPs) and it helped reducing NSP content of the banana tuber meal. Abouelezz et al.
(2018) reported that treatment failed to bind the NSP content on the cassava extraction residue treatment showing that the result did not give significant difference ( $p>$ 0.05). Moreover, the cooked and uncooked banana meal that consisted of NSP could have negative effect on the animals (Atapattu \& Senevirathne 2013). Sjofjan et al. (2021) stated the used of enzyme would inhibit the negative effect of NSP in the duck intestinal. The enzyme could be useful as an endogenous enzyme in the cell wall that supported in breaking dawn the NSP of feedstuff (Sjofjan et al. 2021).

Results of this study showed that $\beta$-cellulose banana tuber meal improved feed conversion ratio (FCR) in growing 1, 2 and finishing phases in comparation to control diet. FCR of growing phase 1 were respectively for M-BTM25, M-BTM50, M-BTM75 and M-BTM100 of $3.81 ; 3.54 ; 3.12,3.55 \mathrm{vs}$. NC (control diet) of 3.87 , and of growing phase 2 , that were $3.31 ; 2.97 ; 2.96 ; 2.95$ vs. 3.34 of $\mathrm{NC}$ diet and finishing phase of 3.33; 3.97; $3.44 ; 3.13$ vs. 3.24 NC diet. However, since we

Table 4. Growth performance of colored-feathered hybrid duck (Pekin x Khaki Campbell), fed modified banana tuber meal (M-BTM) diets at growing phase

\begin{tabular}{|c|c|c|c|c|c|c|}
\hline Performance & $\mathrm{NC}$ & M-BTM 25 & M-BTM50 & M-BTM75 & M-BTM100 & SEM \\
\hline \multicolumn{7}{|l|}{ First growing phase (age of 24-38days) } \\
\hline Initial body weight, (g/bird) & 444 & 447 & 446 & 445 & 448 & 0.32 \\
\hline Body live weight at age of 38 days, (g/bird) & 733 & 714 & 736 & 723 & 747 & 0.22 \\
\hline Daily body weight gain, (g/bird) & $34.5^{\mathrm{b} 2)}$ & $39.1^{\mathrm{a}}$ & $38.3^{\mathrm{ab}}$ & $37.4^{\mathrm{b}}$ & $35.9^{\mathrm{ab}}$ & 1.22 \\
\hline Feed conversion ratio (FCR) & $3.87^{\mathrm{a}}$ & $3.81^{\mathrm{a}}$ & $3.54^{\mathrm{b}}$ & $3.12^{\mathrm{b}}$ & $3.55^{\mathrm{b}}$ & 4.55 \\
\hline Mortalities, (\%) & 0.00 & 0.00 & 0.00 & 1.26 & 0.00 & 0.12 \\
\hline Feed consumption, (g/bird) & 1,622 & 1,614 & 1,523 & 1,512 & 1,563 & 0.11 \\
\hline \multicolumn{7}{|l|}{ Second growing phase (age of 39-52days) } \\
\hline Body live weight at age of 52 days, (g/bird) & 988 & 978 & 976 & 985 & 987 & 0.22 \\
\hline Daily body weight gain, (g/bird) & $56.5^{\mathrm{b}}$ & $59.2^{\mathrm{a}}$ & $58.7^{\mathrm{ab}}$ & $57.8^{\mathrm{b}}$ & $58.9^{\mathrm{ab}}$ & 4.55 \\
\hline Feed conversion ratio & $3.34^{\mathrm{a}}$ & $3.31^{\mathrm{a}}$ & $2.97^{\mathrm{b}}$ & $2.96^{\mathrm{b}}$ & $2.95^{\mathrm{b}}$ & 3.32 \\
\hline Mortalities, $(\%)$ & 0.00 & 1.26 & 0.00 & 1.26 & 1.26 & 0.13 \\
\hline Feed consumption, (g/bird) & 1,813 & 1,834 & 1,717 & 1,652 & 1,543 & 0.14 \\
\hline \multicolumn{7}{|l|}{ Finisher (age of 53-64days) } \\
\hline Body live weight at age of 64 days, (g/bird) & 1558 & 1570 & 1674 & 1562 & 1542 & 24.53 \\
\hline Daily body weight gain, (g/bird) & $54.3^{\mathrm{b}}$ & $59.3^{\mathrm{a}}$ & $58.6^{\mathrm{ab}}$ & $58.3^{\mathrm{b}}$ & $56.1^{\mathrm{ab}}$ & 2.11 \\
\hline Feed conversion ratio & $3.24^{\mathrm{a}}$ & $3.33^{\mathrm{a}}$ & $3.97^{\mathrm{b}}$ & $3.44^{\mathrm{b}}$ & $3.13^{\mathrm{b}}$ & 0.12 \\
\hline Mortalities, (\%) & 4.26 & 3.43 & 0.00 & 1.26 & 3.43 & 0.23 \\
\hline Feed consumption, (g/bird) & 2,033 & 2,003 & 2,118 & 2,534 & 1,592 & 0.19 \\
\hline
\end{tabular}

$\mathrm{NC}=$ negative control; maize-soyabean-meal based diet; M-MBTM25 = 25\% of Modified Banana Tuber Meal replaced maize; M-MBTM50 = $50 \%$ of Modified Banana Tuber Meal replaced maize; M-MBTM75 $=75 \%$ of Modified Banana Tuber Meal replaced maize; M-MBTM100 = $100 \%$ of Modified Banana Tuber Meal replaced maize; SEM = Standard error of mean. Values with different superscript in the same row are significantly difference $(\mathrm{p}<0.05)$ 


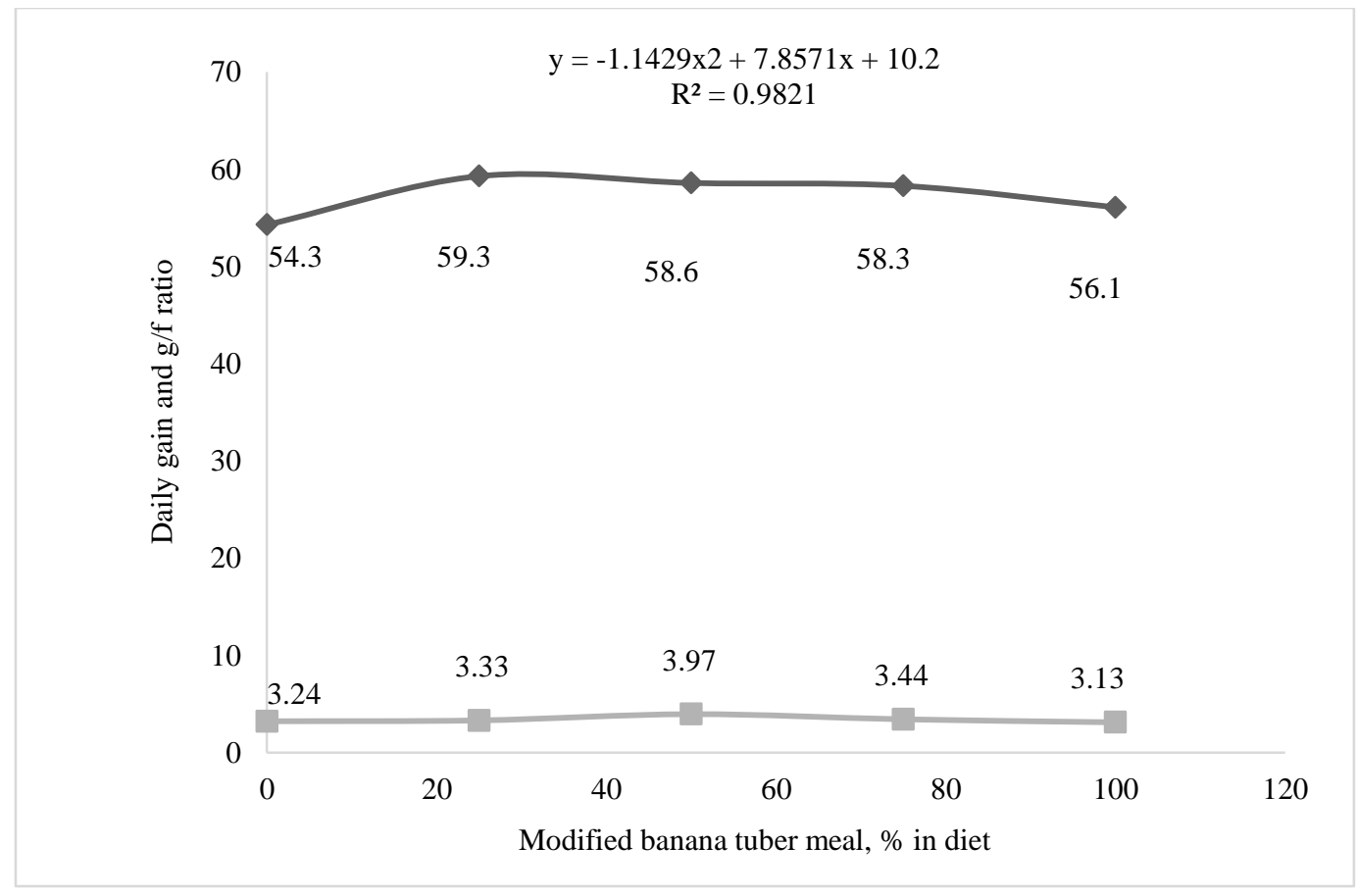

Figure 1. Growth performance of colored-feathered hybrid ducks (Pekin x Khaki Campbell), fed modified banana tuber meal at the age of 64 days. The symbols represent daily gain and feed conversion ratio (ם)

managed controlled-trial environment the response of moderate variable value means were probably expressing the good result achievement. In addition, the breed and environmental factors were considerable evidence in modern rearing strains which had relatively similar in physiological and genetic potential. The hybrid duck used in this study were actually kept in relatively adaptive environment with relatively lower temperatures of $24.11^{\circ} \mathrm{C}$ in the morning and $27.12^{\circ} \mathrm{C}$ in the afternoon and humidity of $61.12 \%$ in morning and $74.22 \%$ in afternoon, had supported sufficient daily feed consumption.

\section{Experimental Diets Digestibility}

The digestibility reflected the impact of Feed conversion ratio (FCR) (Table 5). The result showed used of modified banana tuber meal improved digestibility of dry matter and crude protein significantly $(\mathrm{p}<0.05)$. The digestibility of crude protein of M-BTM diets were $68.22 \%, 67.22 \%, 62.40 \%$ and $66.43 \%$ respectively for M-BTM25, M-BTM50, MBTM75 and M-BTM100 vs $52.57 \%$ was in control diet. In line with nutrient digestibility of dry matter were also increasing, showing of $43.18 \%$; $41.22 \%$; $43.12 \%$; $40.14 \%$ respectively for $25 \%, 50 \%, 75 \%, 100 \%$ of M-TBM diets, vs. $41.11 \%$ for control diet. In this study discrepancy was most probably caused by the protein quality (adequate and balanced amino acid composition) and the presence of anti nutrient components in the diets. There problems in the agro industrial origin were due to anti-nutrients contents such as lectins, polyphenol, anti-nutritional amino acid, saponins, cyanogen glycoside substances, protease inhibitors, and relatively oxalate (Anwar et al. 2016). To reduce anti-nutritional factors there are several technique to increase digestibility using heat, chemicals, machineries, enzyme supplementation, or fermentation (Anwar et al. 2016; (Najoan et al. 2020a; Tien et al. 2014). Compared to Sugiharto et al. (2020) protein digestibility did not vary between banana meal treatment and control, this inference noticed better protein digestibility when feeding banana meal to poultry (Sugiharto et al. 2020).

The modified banana tuber meal for the hybrid ducks did not showed significant effect on the AME, AMEn, TME, and TMEn (Table 6). The AME mean values were 1,$247 ; 1,158 ; 1,086 ; 1,987 \mathrm{kcal} / \mathrm{kg}$ respectively for $25 \%, 50 \%, 75 \%, 100 \%$ M-TBM vs. $1,280 \mathrm{kcal}$ of control treatment, followed by AMEn of dietary treatments of 1,$523 ; 1,456 ; 1,625 ; 1,647 \mathrm{kcal} / \mathrm{kg}$ vs. $1,666 \mathrm{kcal} \mathrm{AMEn} / \mathrm{kg}$ of control. In addition the TME mean values were 2,$122 ; 2,089 ; 2,071 ; 2,074$ $\mathrm{kcal} / \mathrm{kg}$ respectively for $25 \%, 50 \%, 75 \%, 100 \% \mathrm{M}-$ TBM vs. 2,173 kcal TME of control treatment, followed by TMEn of dietary treatments of 1,544; 1,$666 ; 1,752 ; 1,666 \mathrm{kcal} / \mathrm{kg}$ for $25 \%, 50 \%, 75 \%, 100 \%$ M-TBM vs. $1,777 \mathrm{kcal}$ TMEn/kg of control treatment. Reported from Mohammed et al. (2020) the tuber meal containing bitter toxic called gum later called terpenes. 
Table 5. Nutrients digestibility of experimental diets of growing-finisher colored-feathered hybrid duck (Pekin $\mathrm{x}$ Khaki Campbell), fed modified banana tuber meal (M-BTM) diets at age of 64 days

\begin{tabular}{lcccccc}
\hline \hline Nutrient digestibility & NC & M-BTM 25 & M-BTM50 & M-BTM75 & M-BTM100 & SEM \\
\hline Dry matter, (\%) & $41.11^{\mathrm{b}}$ & $43.18^{\mathrm{a} 2)}$ & $41.22^{\mathrm{b}}$ & $43.12^{\mathrm{a}}$ & $40.14^{\mathrm{a}}$ & 0.13 \\
Crude protein, (\%) & $52.57^{\mathrm{b}}$ & $68.22^{\mathrm{a} 2)}$ & $67.22^{\mathrm{a}}$ & $62.04^{\mathrm{ab}}$ & $66.43^{\mathrm{a}}$ & 2.11 \\
AME $(\mathrm{kcal} / \mathrm{kg})$ & 1,280 & 1,247 & 1,158 & 1,086 & 1,937 & 12.11 \\
AMEn (kcal/kg) & 1,666 & 1,523 & 1,456 & 1,625 & 1,647 & 10.13 \\
TME (kcal/kg) & 2,173 & 2,122 & 2,089 & 2,071 & 2,074 & 4.3 \\
TMEn (kcal/kg) & 1,777 & 1,544 & 1,666 & 1,752 & 1,666 & 4.5 \\
\hline
\end{tabular}

$\mathrm{NC}=$ negative control; maize-soyabean-meal based diet; M-MBTM25 = 25\% of Modified Banana Tuber Meal replaced maize; M-MBTM50 = $50 \%$ of Modified Banana Tuber Meal replaced maize; M-MBTM75 $=75 \%$ of Modified Banana Tuber Meal replaced maize; M-MBTM100 = $100 \%$ of Modified Banana Tuber Meal replaced maize; SEM = Standard error of mean. Values with different superscript in the same row are significantly difference $(\mathrm{p}<0.05)$

Table 6. Carcass traits and organs weight of colored-feathered hybrid duck (Pekin x Khaki Campbell), fed modified banana tuber meal at the age of 64 days

\begin{tabular}{|c|c|c|c|c|c|c|}
\hline Meat quality & $\mathrm{NC}$ & M-BTM 25 & M-BTM50 & M-BTM75 & M-BTM100 & SEM \\
\hline Gizzard (\%) & 2.59 & 2.85 & 2.90 & 2.94 & 3.27 & 0.21 \\
\hline Heart (\%) & 2.50 & 2.47 & 2.84 & 2.40 & 2.13 & 0.15 \\
\hline Liver (\%) & 1.92 & 2.40 & 2.54 & 2.56 & 2.71 & 3.11 \\
\hline Spleen $(\%)$ & 0.036 & 0.030 & 0.332 & 0.286 & 0.265 & 0.01 \\
\hline Pancreas $(\%)$ & 1.22 & 1.33 & 1.17 & 1.33 & 1.22 & 0.14 \\
\hline Abdominal fat $(\%)$ & 8.47 & 7.55 & 7.85 & 7.66 & 7.56 & 4.11 \\
\hline Caeca length (\%) & 2.88 & 3.33 & 3.28 & 3.44 & 3.22 & 0.07 \\
\hline Caeca width (\%) & 1.88 & 1.70 & 1.56 & 1.86 & 1.75 & 0.11 \\
\hline Carcass weight (\%) & 45.22 & 46.11 & 47.22 & 46.13 & 45.33 & 4.5 \\
\hline Carcass (\%) & 41.12 & 41.22 & 43.10 & 43.13 & 41.12 & 0.22 \\
\hline Breast meat (\%) & 11.11 & 12.12 & 14.12 & 14.45 & 15.14 & 0.33 \\
\hline Gizzard (g) & 55.99 & 58.05 & 54.26 & 54.60 & 53.67 & 2.33 \\
\hline Heart (g) & 13.03 & 12.63 & 12.59 & 13.53 & 12.59 & 6.13 \\
\hline Liver (g) & 38.78 & 36.89 & 41.25 & 38.78 & 40.25 & 3.41 \\
\hline Spleen (g) & 1.27 & 1.65 & 1.38 & 1.4 & 1.23 & 0.22 \\
\hline Pancreas (g) & 5.38 & 5.64 & 5.73 & 5.93 & 6.04 & 3.1 \\
\hline Abdominal fat (g) & 35.97 & 36.80 & 40.29 & 41.26 & 40.33 & 3.2 \\
\hline Caeca length $(\mathrm{cm})$ & 12.25 & 13.10 & 12.75 & 13.08 & 13.10 & 5.44 \\
\hline Caeca width (cm) & 1.96 & 1.80 & 1.85 & 2.15 & 1.35 & 0.22 \\
\hline Carcass weight (g) & 1204 & 1302 & 1260 & 1293 & 1192 & 235 \\
\hline Carcass (g) & 61.33 & 62.11 & 61.00 & 63.11 & 62.12 & 0.12 \\
\hline Breast meat (g) & 25.11 & 26.12 & 26.12 & 26.13 & 24.14 & 0.12 \\
\hline
\end{tabular}

$\mathrm{NC}=$ negative control; maize-soyabean-meal based diet; M-MBTM25 $=25 \%$ of Modified Banana Tuber Meal replaced maize; M-MBTM50 = $50 \%$ of Modified Banana Tuber Meal replaced maize; M-MBTM75 $=75 \%$ of Modified Banana Tuber Meal replaced meize; M-MBTM100 $=$ $100 \%$ of Modified Banana Tuber Meal replaced maize; SEM = Standard error of mean 
These anti-nutritional factors reduce the digestibility when the raw feed made from tuber given to animals (Mohammed et al. 2020).

\section{Carcass traits}

Carcass traits and relative organ weight emphasis the result of the influence of the modified the banana tuber meal whether it causes damaged or not. The result did not show negative effect on the relative organ weight, and the difference of the treatment means were not significant $(p>0.05)$. Apparently, there were no negative effect detected even in the gizzard. The growth factors correlate with age, while the poultry uses in the relative age cause the same internal organ's growth (Sjofjan et al. 2021). In agreement with Blandon et al. (2015) who stated that the used of banana peels meal replacing maize, were no significant difference $(p>0.05)$ both carcass trait and relative organ weight. The factors affected this result might be due to banana tuber meal contains secondary compounds like terpenoids, flavonoids and others phenolic compounds with a important physiological activity as reported by Blandon et al. (2015) and Fitroh et al. (2018) in banana peels. The terpenoids and flavonoids are anti-nutritional factors that are obstacle in poultry feed. This phenolic compounds are hard to balance with other raw materials as a feed (Blandon et al. 2015). There was only slight reduction $(p>0.05)$ in abdominal fat of the duck fed modified banana tuber meal $(7.55 \% ; 7.85 \% ; 7.66 \%$; $7.56 \%$, respectively for M-BTM25, M-BTM50, MBTM75 and M-BTM100 vs. 8.47\% for control. The use of plantain plant in poultry has been limited because of possibility deleterious effects arising from the presence of tannin (Blandon et al. 2015). Blandon et al. (2015) stated that tannin existed in two forms, namely; (a) free active form caused bitter taste and (b) bound tannin form which are insoluble, supposedly inert and has little or no effect on the palatability but can be useful to reduce abdominal fat (Blandon et al. 2015). In other hand, the report from Najoan et al. (2020a) stated that the flavonoid act can eliminated the abdominal fat which bound into glycine and taurine. The next step is forming glycine and taurine into bile salt and secreted to duodenum which is degraded by microbes (Najoan et al. 2020b).

\section{CONCLUSION}

Result of this study demonstrated the enhancement apparently growth performances and digestibility parameters of colored-feathered hybrid duck (Pekin x Khaki Campbell) after fed modified banana tuber meal (M-BTM) diets.

\section{ACKNOWLEDGMENT}

The author extend appreciation to LPPM, University of Brawijaya for Research Grant flagship for granted Number: 437.18/UN.10.C10/PN/2020 and Non-Tax Revenue (PNBP) UB SP DIPA023.17.2.677512/2020.

\section{REFERENCES}

Abel F, Adeyemi O, Oluwole O, Oladunmoye O, Ayo-Ajasa O, Anuoluwatelemi J. 2015. Effects of treated banana peel meal on the feed efficiency, digestibility and cost effectiveness of broiler chickens diet. J Vet Sci Anim Husb. 3: 101-107.

Abouelezz K, Yuan J, Wang G, Bian G. 2018. The nutritive value of cassava starch extraction residue for growing ducks. Trop Anim Health Prod. 50:1231-1238.

Achilonu M, Shale K, Arthur G, Naidoo K, Mbatha M. 2018. Phytochemical benefits of agroresidues as alternative nutritive dietary resource for pig and poultry farming. J Chem. 2018:1-15.

Ali M, . S, Tamzil MH, Ichsan M. 2014. Meat traits of Muscovy ducks fed on phytonutrition meal. Int J Poult Sci. 13:204-207.

Anwar F, Sriherwanto C, Yunita E, Suja'i I. 2016. Fermentation of kepok banana pell-corn hominy mixed subtrate for dietary inclusion in broiler ration. J Bioteknol Biosains Indones. 3:1-6.

Atapattu NSBM, Senevirathne TSMS. 2013. Effects of increasing levels of dietary cooked and uncooked banana meal on growth performance and carcass parameters of broiler chicken. Pak Vet J. 33:179-182.

Beckford RC, Bartlett JR. 2015. Inclusion levels of sweet potato root meal in the diet of broilers I. Effect on performance, organ weights, and carcass quality. Poult Sci. 94:1316-1322.

Blandon JC, Hamady GAA, Abdel-Moneim MA. 2015. The effect of partial replacement of yellow corn by banana peels with and without enzymes on broiler's performance and blood parameters. J Anim Poult Sci. 4:10-19.

[BPS] Badan Pusat Statistik. 2020. Livestock in Figures 2020. Jakarta (Indones): Badan Pusat Statistik.[BSN] Badan Standardisasi Nasional. 2018. Pakan Itik Penggemukan. Jakarta (Indones): Badan Standardisasi Nasional.

Dei HK, Bacho A, Adeti J, Rose SP. 2011. Nutritive value of false yam (Icacina oliviformis) tuber meal for broiler chickens. Poult Sci. 90:1239-1244.

Fitroh BA, Wihandoyo W, Supadmo S. 2018. The use 3 of banana peel meal (Musa paradisiaca) as Substitution of corn in the diets on performance and carcass production of hybrid ducks. Bul Peternak. 42:222-231.

Hapsari L, Kennedy J, Lestari D, Masrum A, Lestarini W. 2017. Ethnobotanical survey of bananas (Musaceae) in 
six districts of East Java, Indonesia. Biodiversitas. 18:160-174.

Libatique FO. 2020. Growth performance, hematological profile and sensory characteristics of Pekin ducks fed with different levels of Trichanthera gigantea leaf meal. J Crit Rev. 7:134-142.

Mohammed A, Dei HK, Wesseh A, Roessler R, Schlecht E. 2020. Processed false yam seed meals in broiler chicken diets: effects on feed preference and apparent nutrient digestibility. Trop Anim Health Prod. 52:3621-3629.

Mustafa MF, Alimon AR, Zahari MW, Idris I, Hair Bejo M. 2004. Nutrient digestibility of palm kernel cake for Muscovy ducks. Asian-Australasian J Anim Sci. 17:514-517.

Najoan M, Wolayan F, Sompie F, Bagau B. 2020a. Effect of substitution of goroho banana (Musa acuminafe sp.) stem meal fermented with trichoderma viridae in ration on blood lipid profiles and meat quality of broiler chicken, energy (kcal/kg). J Anim sci. 31: 193-196.

Najoan M, Wolayan FR, Sompie FN. 2020b. Nutrient content and bioactive compounds characterization of Goroho banana (Musa acumunafe sp ) stem meal fermented with Trichoderma viride as an alternative feed for broiler chickens. IOP Conf Ser Earth Environ Sci. 492:012010.

Sharmila A, Azhar K, Hezmee MN, Samsudin AA. 2014. Effect of xylanase and cellulase supplementation on growth performance, volatile fatty acids and caecal bacteria of broiler chickens fed with palm kernel meal based diet. J Anim Poult Sci. 3:19-28.

Sjofjan O, Adli DN. 2021. The effect of replacing fish meal with fermented sago larvae (FSL) on broiler performance. Livest Res Rural Dev. 33:17.

Sjofjan O, Adli DN, Natsir MH, Nuningtyas YF, Bastomi I, Amalia FR. 2021. The effect of increasing levels of palm kernel meal containing $\alpha-\beta$-mannanase replacing maize to growing-finishing hybrid duck on growth performance, nutrient digestibility, carcass trait, and VFA. J Indones Trop Anim Agric. 46:29-39.

Steel R, Torrie J. 1990. Statically Analysis System User' Guide.: Statistical Analysis System.

Sugiharto S, Yudiarti T, Isroli I, Widiastuti E, Wahyuni HI, Sartono TA. 2020. Growth performance, haematological responses, intestinal microbiology and carcass traits of broiler chickens fed finisher diets containing two-stage fermented banana peel meal. Trop Anim Health Prod. 52:1425-1433.

Sumardi I, Wulandari M. 2010. Anatomy and morphology character of five Indonesian banana cultivars (Musa spp.) of different ploidy level. Biodiversitas J Biol Divers. 11:167-175.

Tien DTM, Tran NTB, Hang BPT, Preston T. 2014. Performance of common ducks fed an ensiled mixture of banana pseudo-stem and taro (Colocasia esculenta) foliage as a supplement to restricted rice bran and ad libitum fresh duckweed. Livest Res Rural Dev. 26. 